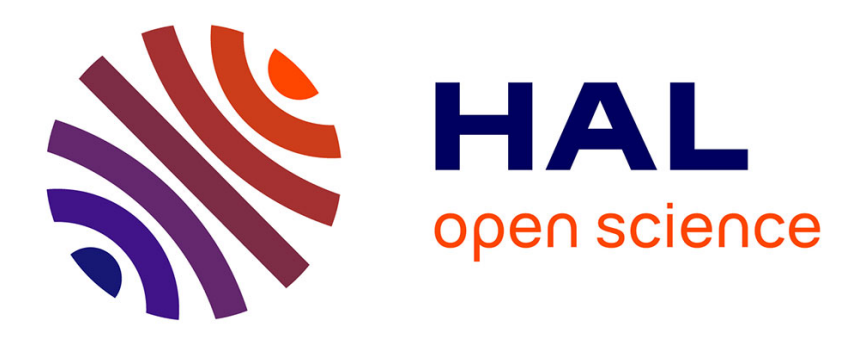

\title{
IN - SITU OPTICAL CHARACTERISATION OF CVD PROCESSES
}

W. Richter, P. Kurpas

\section{To cite this version:}

W. Richter, P. Kurpas. IN - SITU OPTICAL CHARACTERISATION OF CVD PROCESSES. Journal de Physique IV Proceedings, 1991, 02 (C2), pp.C2-153-C2-153. 10.1051/jp4:1991218 . jpa00249805

\section{HAL Id: jpa-00249805 https://hal.science/jpa-00249805}

Submitted on 1 Jan 1991

HAL is a multi-disciplinary open access archive for the deposit and dissemination of scientific research documents, whether they are published or not. The documents may come from teaching and research institutions in France or abroad, or from public or private research centers.
L'archive ouverte pluridisciplinaire HAL, est destinée au dépôt et à la diffusion de documents scientifiques de niveau recherche, publiés ou non, émanant des établissements d'enseignement et de recherche français ou étrangers, des laboratoires publics ou privés. 
Colloque C2, suppl. au Journal de Physique II, Vol. 1, septembre 1991

\title{
IN - SITU OPTICAL CHARACTERISATION OF CVD PROCESSES
}

\author{
W. RICHTER and P. KURPAS \\ Berlin University of Technology, Physics Department, PN 6-1, \\ Hardenbergst. 36, D-1000 Berlin 12, Germany
}

\begin{abstract}
Chemical vapour deposition is determined by gas phase as well as surface processes. Thus, in-situ diagnostics of CVD processes have to deal with the analysis of reactions occurring in the gas phase as well as on the substrate surface where deposition takes place. In both situations probing involves penetration of the gas phase and, therefore, optical probes are the main diagnostic tool for in situ CVD analysis. Ultraviolet (UV), visible (VIS) and near infrared (NIR) optical techniques are commonly used. In the past work has mainly concentrated on gas phase analysis. However, interest has shifted recently to the more difficult study of surfaces.
\end{abstract}

The goal of gas phase diagnostics is to identify all important reactants and to determine their parameters such as concentration and temperature spatially resolved with respect to the substrate position. Optical techniques which have been used, or possibly could be used, in this respect are: UV/NIR absorption, laser induced fluorescent (LIF), Raman scattering and non-linear optical methods such as coherent anti Stokes Raman scattering (CARS). The application of these methods in CVD processes will be discussed in relation to their temporal and spatial resolution as well as their sensitivity. Results from these techniques will be first given for the evaluation of the thermo- and hydrodynamical situations in CVD reactors. This knowledge is required in order to control the homogeneity of growth on the substrate. The larger part of the paper will deal with the analysis of concentrations and from this conclusions will be drawn about possible reaction kinetics. Examples discussed will derive from the epitaxial growth of semiconductors such as $\mathrm{GaAs}$ from $\mathrm{AsH}_{3}$ and $\mathrm{Ga}\left(\mathrm{CH}_{3}\right)_{3}$, silicon from $\mathrm{SiH}_{4}$ and the properties of new precursors for the replacement of the standard but toxic hydrides.

The understanding of surface processes, even though this is the final and most important step in CVD, has in the past mainly been drawn from the results of molecular beam experiments under UHV conditions. But true in situ analysis under typical CVD total pressures seems to be now possible with different surface sensitive techniques, among which Reflectance Anisotropy Spectroscopy (RAS) seems to be the most promising. 